\title{
KETAHANAN SULFAT SEMEN OPC + FLY ASH DENGAN PORLAND COMPOSITE CEMENT (PCC) PADA MUTU BETON K-300
}

\author{
RAJIMAN \\ DEWA GEDE PUTRA \\ Universitas Sang Bumi Ruwa Jurai \\ rajiman.mt@gmail.com \\ dewagedeputra@gmail.com
}

\section{Abstrak}

Industri konstruksi berkaitan erat dengan bangunan beton. Material penyusun beton yang paling utama adalah semen dan semen yang paling banyak digunakan adalah semen murni (clinker). Perkembangan di berbagai bidang industri selain memberi manfaat bagi masyarakat namun juga memberikan masalah yaitu limbah buangan dari industri tersebut. Tujuan Mengetahui pengaruh dari penambahan fly ash yang ditambahkan ke dalam semen murni (klinker) dengan Portland Composite Cement (PCC) terhadap kuat tekan beton yang dihasilkan. Mengetahui pengaruh kuat tekan beton yang mengalami perendaman dengan larutan sulfat. Alur penelitian yang dilakukan dibagi menjadi empat tahap, yaitu: pemeriksaan material, pembuatan rencana campuran (mix design) dan pembuatan benda uji, pelaksanaan pengujian, dan analisis hasil penelitian.Penambahan fly ash ke dalam semen murni (clinker) mengindikasikan terjadinya peningkatan kuat tekan pada beton. Dengan kadar fly ash $10 \%$ pada umur beton 56 hari menghasilkan kuat tekan paling tinggi yaitu mencapai $462,22 \mathrm{~kg} / \mathrm{cm}^{2}$ atau meningkat 18,6\% tanpa perendaman sulfat, sedangkan dengan perendaman suflat menghasilkan kuat tekan $276,30 \mathrm{~kg} / \mathrm{cm}^{2}$ atau meningkat 11,34\%. Berdasarkan hasil uji kuat tekan beton, perendaman dalam larutan sulfat mengakibatkan penurunan kuat tekan beton mencapai 59,77\% dan mengalami kerusakan beton secara fisik.

\section{Abstract}

The construction industry is closely related to concrete buildings. The most important concrete material is the most widely used cement and cement is pure cement (clinker). Developments in various fields of industry in addition to providing benefits for the community but also provide problems of waste from the industry. Objective To determine the effect of adding fly ash added to pure cement (clinker) with Portland Composite Cement (PCC) to the resulting compressive strength of the concrete. Determine the effect of compressive 
strength of concrete that soaked with sulfate solution. The flow of the research is divided into four stages: material examination, mix design and making of specimens, test implementation, and analysis of research results. Addition of fly ash into pure cement (clinker) indicates an increase in compressive strength concrete. With $10 \%$ fly ash content at 56 days of concrete, the highest compressive strength reached $462,22 \mathrm{~kg} / \mathrm{cm} 2$ or increased by $18.6 \%$ without sulphate immersion, while with the soflat immersion yielding a compressive strength of $276,30 \mathrm{~kg} / \mathrm{cm} 2$ or an increase of $11,34 \%$. Based on the result of concrete compressive strength test, soaking in sulfate solution resulted in decrease of concrete compressive strength reached 59,77\% and physically damaged concrete.

Keywords : Construction, PCC, Sulfate, concrete, compressive strength

\section{PENDAHULUAN}

Kemajuan dalam bidang industri terutama dalam industri konstruksi di Indonesia saat ini menunjukkan pertumbuhan yang signifikan, sehingga diperlukan material bangunan dengan jumlah besar untuk mendukung kemajuan industri konstruksi di Indonesia. Industri konstruksi berkaitan erat dengan bangunan beton.

Perkembangan di berbagai bidang industri selain memberi manfaat bagi masyarakat namun juga memberikan masalah yaitu limbah buangan dari industri tersebut. Berbagai cara dilakukan untuk memanfaatkan limbah buangan tersebut, termasuk oleh produsen semen untuk memanfaatkan limbah buangan sebagai bahan campuran dalam pembuatan semen. Salah satu limbah buangan yang dapat dimanfaatkan sebagai bahan campuran semen adalah limbah buangan dari industri batubara yaitu fly ash (abu terbang). PT. Semen Baturaja adalah salah satu industri semen terbesar yang ada di Indonesia yang memproduksi semen jenis PCC (Portland Composite Cement). Semen jenis PCC adalah semen yang dibuat dengan memanfaatkan bahan tambahan anorganik seperti fly ash dan trass. Dalam terapan beton 
terdapat anggapan bahwa semen jenis PCC memiliki karakter yang mirip, bahkan lebih baik bila dibandingkan dengan OPC.

Beton adalah konstruksi bangunan sipil yang paling banyak digunakan saat ini. Hal tersebut dikarenakan beton memiliki beberapa kelebihan dibandingkan dengan bahan-bahan konstruksi lain diantaranya karena harga yang relatif murah (ekonomis), kemampuan menahan gaya tekan yang tinggi, dapat dibentuk sesuai kebutuhan konstruksi yang diinginkan, mudah dalam perawatannya serta ketahanan yang baik terhadap cuaca dan lingkungan sekitar.

Fly ash dan bottom ash merupakan limbah padat yang dihasilkan dari pembakaran batubara pada pembangkit tenaga listrik. Ada tiga type pembakaran batubara pada industri listrik yaitu dry bottom boilers, wetbottomboilers dan cyclon furnace. Apabila batubara dibakar dengan type dry bottomboiler, maka lebih kurang $80 \%$ dari abu meninggalkan pembakaran sebagai flyash dan masuk dalam corong gas. Apabila batubara dibakar dengan wet-bottomboiler sebanyak 50\% dari abu tertinggal di pembakaran dan 50\% lainnya masuk dalam corong gas. Pada cyclon furnace, dimana potongan batubara digunakan sebagai bahan bakar, 70-80 \% dari abu tertahan sebagai boiler slagdan hanya 20-30\% meninggalkan pembakaran sebagai $d r y$ ash pada corong gas.

PLTU merupakan salah satu penyumbang terbanyak untuk produksi limbah fly ash maupun bottom ash karena penggunaan batu-bara sebagai bahan bakar utamanya. Seperti PLTU Tarahan yang terdapat di Provinsi Lampung. Abu terbang yang tertangkap dapat menjadi limbah yang membahayakan makhluk hidup di sekitar area. 


\section{Rajiman \\ Dewa Gede Putra}

Dengan berkembangnya teknologi terutama di bidang ilmu material, saat ini flyash mulai mendapat perhatian lebih dari kalangan peneliti. Sebagai contoh, saat ini material fly ash mulai digunakan sebagai campuran komposisi semen, bangunan rumah, bahkan digunakan dalam pembuatan aspal jalan. Namun penggunaannya belum maksimal, untuk PLTU Tarahan sendiri saja fly ash yang dimanfaatkan hanya 1/3 dari total produksi fly ash perbulan.

Adapun tujuan dari penelitian ini adalah untuk mengetahui pengaruh dari penambahan fly ash yang ditambahkan ke dalam semen murni (klinker) dengan Portland Composite Cement (PCC) terhadap kuat tekan beton yang dihasilkan. Mengetahui pengaruh kuat tekan beton yang mengalami perendaman dengan larutan sulfat.

\section{TINJAUAN PUSTAKA}

\section{Beton}

Beton adalah campuran antara semen portland atau semen hidraulik lain, agregat halus, agregat kasar dan air, dengan atau tanpa bahan tambahan membentuk masa padat.

Mendefinisikan beton sebagai sekumpulan interaksi mekanis dan kimiawi dari material pembentuknya yaitu semen hidrolik (portland cement), agregat kasar, agregat halus, air dan bahan tambahan (admixture atau additive). Sebagai bahan konstruksi, beton mempunyai banyak kelebihan, antara lain dapat dengan mudah dibentuk sesuai kebutuhan serta mampu memikul beban yang berat. Akan tetapi, disamping semua kelebihannya, beton juga mempunyai kekurangan antara lain bersifat getas, tidak kuat menahan tegangan tarik, dan kurang baik menahan beban lentur. 
Kemampuan beton memikul beban yang berat berkaitan dengan kekuatan tekan beton. Kekuatan tekan adalah kemampuan beton untuk menerima gaya tekan per satuan luas. Ada empat bagian utama yang mempengaruhi kekuatan beton, yaitu proporsi bahan-bahan penyusunnya, metode perancangan, perawatan, dan keadaan pada saat pengecoran dilaksanakan terutama dipengaruhi oleh lingkungan setempat. Kekuatan akhir beton banyak dipengaruhi oleh agregat kasar dan matrik semen-pasir, namun ada hal lain yang juga penting dan mempengaruhi kuat tekan beton, yaitu ikatan antara permukaan (interface) antara agregat kasar dan matriks semen-pasir. Interface merupakan suatu daerah peralihan sebesar 30 um di sekeliling agregat kasar dan matriks semen-pasir.

Berdasarkan kekuatannya beton dapat dibedakan menjadi tiga, yaitu, beton normal kuat tekannya antara 17,5 Mpa- $41 \mathrm{Mpa}$, beton mutu tinggi memiliki kuat tekan antara $>41 \mathrm{Mpa}-83 \mathrm{Mpa}$, dan beton mutu sangat tinggi yang memiliki kuat tekan > $83 \mathrm{Mpa}$.

\section{Semen Portland Biasa}

Semen merupakan bahan campuran beton yang bereaksi aktif terhadap air (semes hidrolik) atau udara (semen non-hidrolik). Fungsi utama semen pada adukan beton adalah mengikat butir-butir agregat hingga membentuk suatu massa yang padat dan mengisi rongga-rongga udara di antara butir-butir agregat. Menurut ASTM C-150, 1985, semen portland didefinisikan sebagai semen hidrolik yang dihasilkan dengan menggiling klinker yang terdiri dari kalsium silikat hidrolik yang umumnya mengandung satu atau lebih bentuk kalsium sulfat sebagai bahan tambahan yang. digiling bersama-sama dengan bahan utamanya. Komposisi yang sebenarnya dari berbagai senyawa yang ada berbeda-beda dari jenis semen yang satu dengan yang lainnya. Semen 


\section{Rajiman \\ Dewa Gede Putra}

Portland Biasa (Ordinary Portland Cement) biasanya digunakan dalam pelaksanaan konstruksi beton secara umum apabila tidak diperlukan sifatsifat khusus, misalnya ketahanan terhadap sulfat, panas hidrasi rendah, kekuatan awal yang tinggi dan sebagainya. ASTM mengklasifikasikan semen jenis ini sebagai semen tipe 1 .

\section{Semen Portland Komposit}

Semen portland komposit didefinisikan sebagai bahan pengikat hidrolis hasil penggilingan bersama-sama terak semen portland dan gips- dengan satu atau lebih bahan anorganik, atau hasil pencampuran antara bubuk semen portland dengan bubuk bahan anorganik lain. Bahan anorganik tersebut antara lain terak tanur tinggi (blast jurnace slag) pozzolan, senyawa silikat, batu kapur, dengan kadar total bahan anorganik 6 - 35\% dari massa semen portland komposit. Menurut Supartono (2001:12) bahan-bahan anorganik tersebut merupakan bahan-bahan mineral yaug memiliki sifat pozzolanik, yaitu bahan-bahan mineral yang unsur-unsurnya tidak memiliki sifat semen secara mandiri, namun bila bereaksi dengan kalsium-oksida dan air pada temperatur biasa, bisa membentuk senyawa yang mempunyai ciri-ciri semen (cementitious).

\section{Agregat}

Agregat adalah butiran mineral alami yang berfungsi sebagai bahan pengisi dalam campuran mortar atau beton. Agregat ini menempati sebanyak $60 \%$ $80 \%$ dari volume mortar atau beton. Meskipun hanya sebagai bahan pengisi, tetapi agregat sangat berpengaruh terhadap sifat mortar atau beton. Bentuk, tekstur, dan gradasi agregat mempengaruhi sifat pengikatan dan pengerasan beton segar. Sedangkan sifat fisik, kimia, dan mineral mempengaruhi kekuatan, kekerasan dan ketahanan dari beton, sehingga pemilihan agregat 
merupakan suatu bagian yang penting dalam pembuatan mortar atau beton. Secara umum, agregat penyusun beton dapat dibedakan menjadi agregat kasar dan agregat halus.

Ukuran agregat kasar sangat mempengaruhi kekuatan tekan beton. Semakin besar agregat maksimum yang digunakan, semakin berkurang kekuatan beton yang dihasilkan. Hal ini dikarenakan semakin besar agregat kasar, ruang antara agregat yang dihasilkan semakin besar sehingga potensi terjadinya void akan semakin tinggi. Semakin banyak void yang ada pada beton maka akan semakin kecil kekuatan tekannya.

Menurut standar ASTM, agregat halus adalah batuan yang ukuran butirnya lebih kecil dari 4,75 mm (ASTM C33, 1994). Agregat halus adalah salah satu unsur beton yang berfungsi mengisi pori-pori yang ada diantara agregat kasar, sehingga diharapkan dapat meminimalkan kandungan udara dalam beton yang dapat mengurangi kekuatan beton.

\section{Abu Terbang (Fly Ash)}

Abu terbang merupakan limbah pembakaran batu bara yang butirannya lebih talus daripada semen Portland, yang mempunyai sifat-sifat hidrolik. Produksi abu terbang batubara (fly ash) di dunia pada tahun 2000 diperkirakan berjumlah 349 milyar ton. Penyumbang produksi abu terbang batubara terbesar adalah sektor pembangkit listrik. Produksi abu terbang dari pembangkit listrik di Indonesia terus meningkat, pada tahun 2000 jumlahnya mencapai 1,66 milyar ton dan mencapai 2 milyar ton pada tahun 2006.

Komponen utama dari abu terbang batubara yang berasal dari pembangkit listrik adalah silika $\left(\mathrm{SiO}_{2}\right)$, alumina, $\left(\mathrm{Al}_{2} \mathrm{O}_{3}\right)$, dan besi oksida $\left(\mathrm{Fe}_{2} \mathrm{O}_{3}\right)$, sisanya adalah karbon, kalsium, magnesium, dan belerang. 


\section{Rajiman \\ Dewa Gede Putra}

Sementara itu dalam penelitian Yamamoto (2006) menyebutkan bahwa fly ash ditambahkan selama reaksi hidrasi dimana semen dan air bereaksi dalam satu kesatuan, hal itu menyebabkan reaksi kimia dalam waktu yang lama membentuk fese glass seperti silika dan alumunium dengan semen hidrat (kalsium hidroksida). Sifat-sifat fly ash tergantung pada sumber batu bara dan proses pembakaran yang ada di pembangkit listrik.

\section{Sulfat}

Sulfat merupakan sejenis anion poliatom dengan rumus empiris $\mathrm{SO}_{4}{ }^{2-}$ dengan massa molekul 96.06 satuan massa atom, sulfat terdiri dari atom pusat sulfur dikelilingi oleh empat atom oksigen dalam susunan tetrahidron. Sulfat merupakan senyawa yang stabil secara kimia karena merupakan bentuk oksida paling tinggi dari unsur belerang. Sulfat dapat dibasilkan dari oksida senyawa sulfida oleh bakteri. Sulfat di dalam lingkungan (air) dapat berada secara ilmiah dan atau dari aktivitas manusia, misalnya dari limbah industry dan limbah laboratorium. Secara ilmiah sulfat biasanya berasal dari pelarutan mineral yang mengandung S, misalnya gips (CaSO4.2H2O) dan kalsium sufat anhidrat (CaSO4).

Garam-garam sulfat yang umum terdapat secara alami dalam tanah merupakan garam-garam sulfat yang merugikan karena merupakan kontaminasi sulfat akibat adanya reaksi kimia yang ditimbulkan dengan semen atau beton. Garam-garam tersebut adalah Natrium sulfat dan Magnesium sulfat, yang banyak ditanah alkali. Garam-garam tersebut mempunyai dampak yang lebih merugikan daripada kerugian yang ditimbulkan oleh gips (Kalsium sulfat), karena garam-garam tersebut tidak hanya lebih mudah larut, tetapi juga menghasilkan konsentrasi sulfat yang 
lebih besar dalam air tanah dan bereaksi dengan mineral semen, sehingga menyebabkan kerusakan total pada pasta semen (Masruri, 1993).

Menurut Husin (2010) pengrusakan akibat senyawa sulfat pada semen dapat dituangkan mekanismenya sebagai berikut:

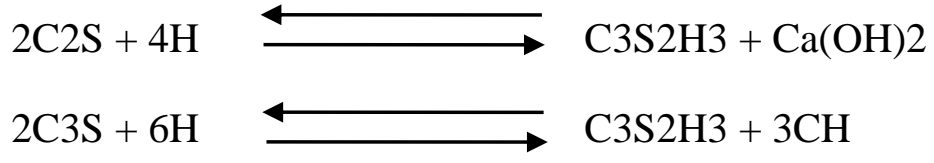

Jadi bila semen mengeras, tiap molekul dikalsium silikat akan membebaskan 0,5 mol kapur dan tiap mol trikalsium silikat akan melepaskan 1,5 mol kapur. Jadi bila semen Portland yang dipakai tinggi kadar C3 nya, kapur yang akan dibebaskan selama semen mengeras akan lebih besar, dibanding dengan semen yang kadar C2 nya tinggi. Terjadinya pembebasan kapur selama semen mengeras, maka pada pasta semen terbentuk saluran kapiler, dimana $\mathrm{Ca}(\mathrm{OH}) 2$ akan mengalir keluar (bila ia dapatmengalir) atau pada saluran itu terisi kapur. Bila pasta terendam dalam larutan yang mengandung $\mathrm{SO}_{4}-$ maka kapur tadi akan bersenyawa membentuk gips. $\mathrm{CaSO}_{4}$, terbentuknya Kalsium sulfat ini bila kemudian suasananya kering, gips akan membentuk kristal yang seperti jarum dan mengembang, mendesak sisi sekitarnya sehingga terjadi pengrusakan pada sisi sekitar itu dan dapat terlihat pasta atau adukan betonnya merapuh. Bila setelah terbentuk gips kondisi basah (lembab) maka gips terjadinya reaksi (1) tergantung pada kondisi. Dalam air yang mengalir, dengan supply garam Natrium suifat dan keluarnya Natrium hidroksida yang konstan, reaksi tersebut tidak pernah selesai atau sempurna. Natrium hidroksida mengumpul sampai akan dicapai suatu keseimbangan, tergantung pada konsentrasi Natrium suifat. Kemudian dengan $5 \%$ Na2SO4 hanya kirakira sepertiga dari Sulfur trioksida yang ditimbun sebagai Kalsium suifat apabila keseimbangan tercapai dan dengan larutan $2 \% \mathrm{Na} 2 \mathrm{SO} 4$ hanya kira- 


\section{Rajiman \\ Dewa Gede Putra}

kira seperlimanya. Dengan Kalsium suifat hanya reaksi (2) dapat terjadi. Alkali suifat tidak menyerang Kalsium silikat hidrat. Untuk beberapa tingkat reaksi cukup besar, karena lebih tidak larut daripada Kalsium suifat dan akan dihasilkan Alkali silikat. Kalsium hidroksida dihasilkan dalam proses pengerasan tri. dan di kalsium silikat bereaksi menurut persamaan (3). Kristal dari gypsum segera terbentuk dari tri kalsium siiikat, tetapi dengan di kalsium silikat reaksi berlangsung lebih lambat, cocok dengan kecepatan yang sangat lambat pada senyawa splits dari Kalsium hidroksida dalam air. Magnesium sulfat mempunyai keseimbangan yang tercapai lebih jauh daripada sulfat lainnya dan menguraikan Kalsium silikat hidratberlebih bila bereaksi dengan Aluminat dan Kalsium hidrat. Apabila tri ataudikalsium silikat berada dalam larutan Magnesium sulfat, pembentukan kristalgypsum terjadi sangat cepat. Kalsium silikat hidrat bereaksi umumnya sebagai berikut:

$3 \mathrm{CaO} 2 \mathrm{SiO} 2 \mathrm{aq}+3 \mathrm{MgSO} 47 \mathrm{H} 2 \mathrm{O} \longrightarrow \mathrm{CaSO} 42 \mathrm{H} 2 \mathrm{O}+3 \mathrm{Mg}(\mathrm{OH}) 2+$ $2 \mathrm{SiO} 2 \mathrm{aq}$

Alasannya kenapa peristiwa ini berlangsung sempurna, sedang dengan Natrium sulfat tidak terjadi. Hal itu didapatkan dalam kelarutan yang rendah dari Magnesium hidroksida dan menghasilkan $\mathrm{pH}$ rendah dalam larutan yang jenuh dan hanya larut pada tingkat kira-kira $0,01 \mathrm{~g} / \mathrm{L}$. Larutan jenuhnya mempunyai $\mathrm{pH}$ kira-kira 10,5. Ini lebih rendah daripada $\mathrm{pH}$ yang dibutuhkan untuk menstabilkan Kalsium silikat hidrat.

\section{Kuat Tekan Beton}

Kuat tekan beton adalah besarnya beban persatuan luas, yang menyebabkan benda uji beton hancur bila dibebani dengan gaya tekan yang dihasilkan oleh mesin penekan (Compression Testing Machine). Menurut ASTM C39-93a, kuat tekan beton dihitung dengan cara membagi beban maksimum selama 
pengujian dengan luas pennukaan beton kubus. Secara matematis dapat ditulis sebagai berikut:

$$
\sigma_{c}=\frac{P}{A}
$$

dengan :

$\sigma_{\mathrm{c}}=$ kuat tekan beton $(\mathrm{kg} / \mathrm{cm})$

$\mathrm{P} \quad=\quad$ beban tekan maksimum $(\mathrm{KN})$

$\mathrm{A}=$ luas penampang tertekan $\left(\mathrm{cm}^{2}\right)$

Kuat tekan dari beton dipengaruhi oleh sejumlah faktor, antara lain faktor air semen dan tingkat kepadatannya. Selain kedua hal tersebut, faktor-faktor lain yang tidak kalah penting adalah :

\section{Rancangan Campuran}

Campuran beton merupakan perpaduan dari komposit material penyusunnya. Karakteristik dan sifat dari masing-masing bahan penyusun beton tersebut akan mempengaruhi hasil rancangan. Pembuatan suatu perancangan campuran (mix design), pada dasarnya dimaksudkan untuk menghasilkan suatu proporsi campuran yang optimal dengan kekuatan maksimum. Dalam hal ini, langkah pertama yang paling penting sebelum melaksanakan rancang campuran beton adalah pemilihan; material penyusunnya, seperti agregat, semen, dan air. Bahan penyusun yang memiliki kualitas yang baik pada umumnya juga akan menghasilkan beton dengaa kekuatan tekan yang baik. Setelah menemukan bahan penyusun berkualitas baik, selanjutnya dilakukan rancang campuran untuk mencapai kekuatan beton dan workability adukan yang dispesifikasikan.

Pada penelitian ini rencana komposisi campuran beton (mix design) mengacu pada peraturan ACI 318-89. Kuat tekan beton yang direncanakan adalah K- 


\section{Rajiman}

\section{Dewa Gede Putra}

300 dengan slump rencana 75 - $100 \mathrm{~mm}$. Ukuran agregat maksimum yang direncanakan adalah $20 \mathrm{~mm}$, Penggunaan semen portland komposit yaitu dengan menggunakan semen jenis PCC.

\section{Standart Deviasi}

Standar deviasi merupakan ukuran penyebaran yang paling banyak digunakan. Semua gugus data dipertimbangkan sehingga lebih stabil dibandingkan dengan ukuran lainnya. Namun, apabila dalam gugus data tersebut terdapat nilai ekstrem, standar deviasi menjadi tidak sensitif lagi, sama halnya seperti mean.

Standar Deviasi memiliki beberapa karakteristik khusus lainnya. SD tidak berubah apabila setiap unsur pada gugus datanya di tambahkan atau dikurangkan dengan nilai konstan tertentu. SD berubah apabila setiap unsur pada gugus datanya dikali/dibagi dengan nilai konstan tertentu. Bila dikalikan dengan nilai konstan, standar deviasi yang dihasilkan akan setara dengan hasilkali dari nilai standar deviasi aktual dengan konstan.

Untuk data sample menggunakan rumus:

$$
S-\sqrt{\frac{\sum_{i=1}^{n}\left(\boldsymbol{x}_{i}-\bar{x}\right)^{2}}{n-1}}
$$

Untuk data populasi menggunkan rumus:

$$
\sigma=\sqrt{\frac{\sum_{i=1}^{2}\left(x_{i}-\mu\right)^{2}}{n}}
$$




\section{METODE PENELITIAN}

Bahan material yang digunakan dalam penelitian adalah:

\section{Semen}

Semen yang digunakan adalah semen murni (klinker) asal PT. Baturaja dan Portland Composite Cement (PCC), dalam kemasan $50 \mathrm{~kg} / \mathrm{sak}$ yang diperoleh dari toko dalam keadaan baik dan tertutup rapat.

\section{Fly Ash (Abu Terbang)}

Fly ash yang digunakan berasal dari pabrik batubara yang ada di daerah Tarahan, Lampung Selatan. Fly ash ini beriungsi sebagai pengganti sejumlah semen OPC.

\section{AgregatHalus}

Agregat halus yang digunakan berasal dari Tanjung Bintang, Lampung Selatan yang terlebih dahulu diperiksa kadar lumpur, bahan organis, analisis saringan, berat jenis dan penyerapan, dan kadar airnya (memenuhi ASTM C 33).

\section{Agregat Kasar (Batu Pecah)}

Digunakan batu pecah putih yang diperoleh dari Tanjungan Lampung Selatanyang merupakan hasil produksi stone crusher, dengan diameter maksimum $20 \mathrm{~mm}$ Agregat kasar ini terlebih dahulu diuji berat jehis dan penyerapan agregat kasar, serta analisis saringannya (memenuhi ASTM C $33)$.

\section{Sulfat}

Larutan sulfat yang digunakan adalah sulfat pekat yang diperoleh dari toko 


\section{Rajiman}

\section{Dewa Gede Putra}

yang kemudian dilarutkan dengan menggunakan air sampai didapat larutan sulfat dengan konsentrasi $5 \%$.

\section{Air}

Air yang digunakan berasal dari Laboratorium Bahan dan Konstruksi FakultasTeknik Universitas Lampung yang telah memenuhi persyaratan untuk air minum.

Dalam penelitian alat yang digunakan adalah sebagai berikut:

\section{Compression Testing Machine}

Mesin ini berkapasitas beban maksimum 150 ton dengan ketelitian 0,5 ton. Alat ini dipakai pada pengujian kuat tekan dengan kecepatan pembebanan sebesar 0,14 - 0,34 Mpa/det.

\section{Mesin Pengaduk Beton (concrete mixer)}

Concrete mixer yang digunakan memiliki kapasitas $0,125 \mathrm{~m}^{3}$ dengan kecepatan 20 -30 putaran per merit yang digerakkan dengan menggunakan diesel. Alat ini berfungsi untuk mengaduk bahan campuran beton.

\section{Slump Test Apparatus}

Kerucut Abrams digunakan beserta tilam pelat baja dan tongkat besi untuk mengetahui kelecakan (workability) adukan dengan percobaan Slump Test. Ukuran kerucut Abrams adalah diameter bawah $200 \mathrm{~mm}$ dan diameter bagian atas $100 \mathrm{~mm}$ dengan tinggi $300 \mathrm{~mm}$.

\section{Cetakan Benda Uji}

Cetakan beton yang digunakan untuk mencetak benda uji berbentuk kubus denganukuran $15 \mathrm{cmx} 15 \mathrm{cmx} 15 \mathrm{~cm}$. 


\section{Timbangan}

Timbangan digunakan untuk pemeriksaan seluruh agregat dan untuk memastikanberat masing-masing komposisi campuran beton.

\section{Oven}

Alat ini digunakan untuk mengeringkan bahan campuran beton yang perlu dikeringkan terlebih dahulu pada saat pemeriksaan.

\section{Saringan}

Alat ini berguna untuk mengetahui gradasi agregat sehingga dapat dapatditentukan nilai modulus kehalusan butir agregat kasar dan agregat halus. Untuk penelitian ini gradasi agregat kasar dan agregat halus berdasarkan standar ASTMC-33.

\section{Piknomeler}

Alat ini digunakan untuk mengetahui beidt jenis SSD (Surface Saturated Dry) berat jenis kering, berat jenis'jenuh, dan penyerapan agregat halus.

\section{Mesin getar dalam (internal vibrator)}

Mesin getar dalam (internal vibrator) digunakan untuk memadatkan adukan beton pada saat memasukkan adukan beton ke dalam cetakan. Tujuannya untuk menghilangkan rongga-rongga udara dan untuk mendapatkan kepadatan yang maksimal serta menjamin suatu perekatan antara material penyusun beton.

\section{Alur Penelitian}

Alur penelitian yang dilakukan dibagi menjadi empat tahap, yaitu: pemeriksaan material, pembuatan rencana campuran (mix design) dan pembuatan benda uji, pelaksanaan pengujian, dan analisis hasil penelitian. 


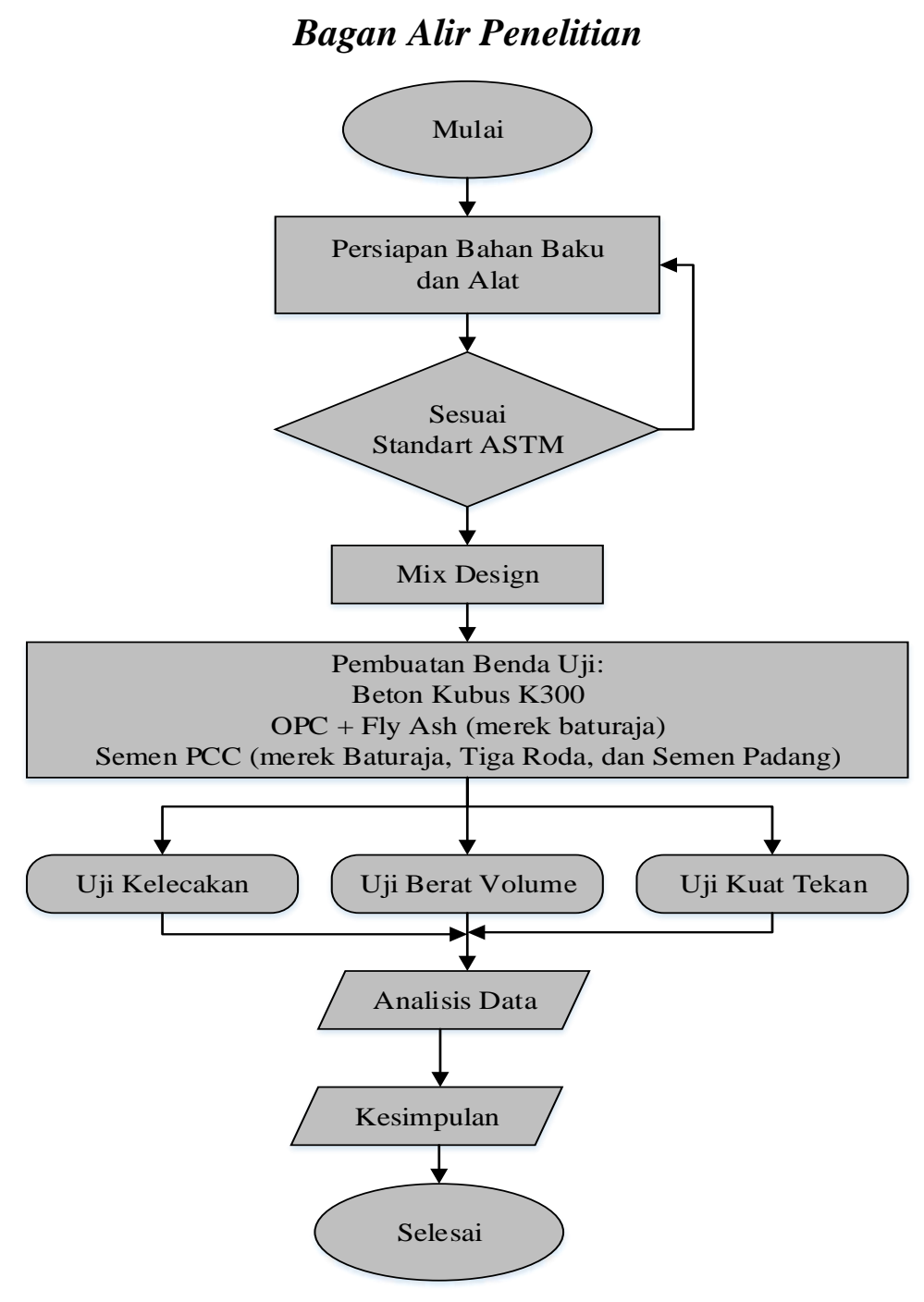

Gambar 1. Bagan Alir Penelitian

\section{HASIL DAN PEMBAHASAN}

Penelitian dilakukan secara eksperimental yang dilaksanakan di Laboratorium PT. Semen batu Raja. Penelitian ini dilakukan terhadap pengaruh penambahan fly ash (abu terbang) pada semen murni atau OPC (Ordinary Portland Cement) dengan semen PCC (Portland Composite Cement) terhadap kuat tekannya apabila direndam dalam larutan sulfat. 
Adapun data hasil dari pengujian yang telah dilakukan akan dibahas lebih detail pada penjelasan di bawah ini.

\section{Hasil Pengujian Material}

Pengujian material dimaksudkan untuk mengetahui data awal mengenai material yang akan digunakan pada campuran beton. Data awal itu antara lain modulus kehalusan agregat, berat jenis relatif, kapasitas absorsi, berat isi padat kering dan ukuran agregat. Data-data yang didapat akan dipergunakan sebagai acuan perhitungan campuran beton. Adapun data-data yang diperoleh dapat dilihat pada tabel 1 berikut ini:

Tabel 1. Hasil Pemeriksaaan Pengujian Bahan Penyusun Beton

\begin{tabular}{c|c|c|c}
\hline \multirow{2}{*}{ Jenis pengujian } & $\begin{array}{c}\text { Material yang } \\
\text { digunakan }\end{array}$ & Nilai hasil pengujian & Standar ASTM \\
\hline \multirow{2}{*}{ Modulus kehalusan } & Agregat kasar & 6,9075 & $6,0-8,0$ \\
\cline { 2 - 4 } & Agregat halus & 3,00 & $2,9-3,1$ \\
\hline \multirow{2}{*}{ Beratjenis } & Agregat kasar & 2,513 & $2,5-2.9$ \\
\cline { 2 - 4 } & Agregat halus & 2,54 & $2,5-2.9$ \\
\hline \multirow{2}{*}{ Penyerapan } & Agregat kasar & $2,95 \%$ & $1-3 \%$ \\
\cline { 2 - 4 } & Agregat halus & $1,2 \%$ & $1-3 \%$ \\
\hline \multirow{2}{*}{ KadarAir } & Agregat kasar & $2,43 \%$ & $0-3 \%$ \\
\cline { 2 - 4 } & Agregat halus & $0.7 \%$ & $<-1 \%$ \\
\hline Kadar lumpur & Agregat halus & $2,1 \%$ & - \\
\hline \multirow{2}{*}{ Berat volume } & Agregat kasar & $1,475 \mathrm{gr} / \mathrm{cm}^{3}$ & - \\
\cline { 2 - 4 } & Agregat halus & $1,45 \mathrm{gr} / \mathrm{cm}^{3}$ & $\begin{array}{c}\text { Tidak boleh lebih } \\
\text { terang dari warna } \\
\text { standar }\end{array}$ \\
\hline \multirow{2}{*}{ Kandungan Zat Organik } & Agregat Halus & warna standar & \\
\hline
\end{tabular}

(Sumber: hasil uji laboratorium)

Berdasarkan data hasil uji pada Tabel 2 menunjukkan bahwa material penyusun beton tersebut telah memenuhi standar ASTM.

\section{Kelecakan (Workability)}

Kelecakan adukan beton (workability) dapat diketahui dengan pengujian nilai slump. ACI mendeflnisikan kelecakan beton (workability) adalah sifat-sifat 
adukan beton atau mortar yang ditentukan oleh kemudahan dalam pencampuran, pengangkutan, pencetakan, pemadatan, dan finishing. Prosedur pengujian kelecakan adukan beton mengacu pada peraturan standar ASTM C-143.

Pengujian kelecakan dilakukan dengan cara slump test pada masing-masing adukan beton mutu K300. Nilai slump beton masing-masing campuran adukan beton disajikan pada Tabel 2 .

Tabel 2. Hasil pengukuran nilai slump pada beton mutu K300

\begin{tabular}{c|l|c|c|c}
\hline No. & \multicolumn{1}{|c|}{ Jenis Semen } & Mutu & Slump $(\mathbf{c m})$ & Slump Rencana (cm) \\
\hline 1 & OPC Baturaja & K300 & 3,1 & $7,5-10$ \\
\hline 2 & OPC Baturaja+5\% fly ash & K300 & 3,3 & $7,5-10$ \\
\hline 3 & OPC Baturaja + 10\% Flyash & K300 & 4,2 & $7,5-10$ \\
\hline 4 & OPC Baturaja+15\% fly ash & K300 & 5,4 & $7,5-10$ \\
\hline 5 & OPC Baturaja +20\% Fly ash & K30C & 6 & $7,5-10$ \\
\hline 6 & PCC Baturaja & K300 & 4 & $7,5-10$ \\
\hline 7 & PCCTigaRoda & K300 & 3,8 & $7,5-10$ \\
\hline 8 & PCC Semen Padang & K300 & 4 & $7,5-10$ \\
\hline
\end{tabular}

(Sumber: hasil uji laboratorium)

Dari Tabel 2 dapat terlihat bahwa penggantian sejumlah semen dengan fly ash mempengamhi tingkat kelecakan beton, semakin banyak jumlah kandungan fly ash yang digunakan maka tingkat kelecakan beton akan semakin tinggi dan menyebabkan nilai slump juga semakin tinggi. Meskipun nilai slump akibat penggantian dengan fly ash meningkat, akan tetapi nilai slump yang dihasilkan tidak sesuai dengan slumprencana yang direncanakan. Hal ini disebabkan karena dalam perencanaan mix untuk mutu beton K300 menggunakan nilai faktor air semen (fas) yang kecil 0,50. Karena menggunakan nilai fas yang kecil sehingga menghasilkan nilai slump yang kecil pula. Slump yang dihasilkan untuk fas 0,4 - 0,5 adalah berkisar antara 2 - $4 \mathrm{~cm}$ (Mulyono, 2004). Sehingga slump yang didapatkan dalam penelitian ini dapat digunakan karena berkisar antara 3-4 cm. 


\section{Berat Volume Beton}

Berat volume beton didapatkan dengan cara membagi berat beton dengan volumenya, beratnya didapat dari menimbang sampel sebelum diuji kuat tekannya. Penimbangan dilakukan pada saat beton sudah mengering. Untuk benda uji dengan umur pengujian 7 hari, sampel diangkat dari rendaman 3 hari sebelum hari pengujian, sedangkan untuk beton dengan umur pengujian 28 hari dan 56 hari, beton diangkat seminggu sebelum pengujian agar beton benar-benar sudah mengering saat dilakukan penimbangan. Hasil dari penimbangan kemudian dikonversi ke dalam satuan berat volume yaitu $\mathrm{kg} / \mathrm{m}^{3}$. Hasil pengukuran berat volume dapat dilihat dari Tabel 3 berikut ini:

Tabel 3. Hasil Pengukuran Berat Volume Beton K300 (Tanpa Perendaman Sulfat)

\begin{tabular}{c|c|c|c|c}
\hline \multirow{2}{*}{ Jenis Semen } & Kandungan & \multicolumn{3}{|c}{ Berat Volume (kg/m } \\
\cline { 3 - 5 } & Fly Ash (\%) & $\mathbf{7 ~ H a r i}$ & $\mathbf{2 8 ~ H a r i}$ & $\mathbf{5 6}$ Hari \\
\hline OPC Baturaja & $0 \%$ & 2377,28 & 2417,58 & 2391,90 \\
\hline OPC Baturaja & $5 \%$ & 2373,14 & 2387,95 & 2382,62 \\
\hline OPC Baturaja & $10 \%$ & 2368,89 & 2380,54 & 2375,21 \\
\hline OPC Baturaja & $15 \%$ & 2362,47 & 2367,21 & 2364,74 \\
\hline OPC Baturaja & $20 \%$ & 2357,83 & 2357,53 & $2362^{\wedge} 7$ \\
\hline PCC Baturaja & $0 \%$ & 2372,84 & 2346,67 & 2336,99 \\
\hline
\end{tabular}

(Sumber: hasil uji laboratorium)

Tabel 1. Hasil Pengukuran Berat Volume Beton K300 (Dengan Perendaman Sulfat)

\begin{tabular}{c|c|c|c|c}
\hline \multirow{2}{*}{ Jenis Semen } & Kandungan & \multicolumn{3}{|c}{ Berat Volume (kg/m $\left.^{\mathbf{3}}\right)$} \\
\cline { 3 - 5 } & Fly Ash (\%) & $\mathbf{7 ~ H a r i}$ & $\mathbf{2 8 ~ H a r i}$ & $\mathbf{5 6 ~ H a r i}$ \\
\hline OPC Baturaja & $0 \%$ & 2319,60 & 2294,32 & 2325,73 \\
\hline OPC Baturaja & $5 \%$ & 2321,88 & 2306,47 & 2351,01 \\
\hline OPC Baturaja & $10 \%$ & 2323,26 & 2317,04 & 2377,68 \\
\hline OPC Baturaja & $15 \%$ & 2362,17 & 2347,95 & 2387,06 \\
\hline OPC Baturaja & $20 \%$ & 2368,79 & 2355,85 & 2396,94 \\
\hline PCC Baturaja & $0 \%$ & 2336,59 & 2331,95 & 2314,57 \\
\hline PCCTigaRoda & $0 \%$ & 2362,17 & 2344,00 & 2391,70 \\
\hline $\begin{array}{c}\text { PCC Semen } \\
\text { Padang }\end{array}$ & $0 \%$ & 2366,42 & 2367,51 & 2365,33 \\
\hline
\end{tabular}

(Sumber: hasil uji laboratorium) 
Dari tabel berat volume di atas dapat terlihat penurunan pada tabel 3 dan peningkatan berat volume pada tabel 4.. Semakin besar kadar fly ash yang digunakan maka akan semakin mempengaruhi berat volume karena berat ferns fly lebih kecil dari pada berat jenis semen. Untuk beton dengan perendaman air biasa, semakin banyak kadar fly ash yang terkandung maka berat volume beton akan semakin ringan, sedangkan untuk beton dengan perendaman larutan sulfat $5 \%$ yang terjadi justru sebaliknya, semakin banyak kandungan fly ash, berat volume beton semakin meningkat meskipun tidak terlalu besar perbedaannya. Beton dari semen murni (klinker) yang memang sifatnya kurang tahan dengan serangan sulfat mengalami penurunan berat volume yang cukup besar. Namun dengan penambahan fly ash, berat volume beton yang direndam dalam larutan sulfat semakin bertambah karena memang sifat fly ash yang menambah kelecakan dan daya lekat beton karena fly ash mengandung senyawa silika $\left(\mathrm{SiO}_{2}\right)$, alumina $\left(\mathrm{Al}_{2} \mathrm{O}_{3}\right)$, dan besi oksida $\left(\mathrm{Fe}_{2} \mathrm{O}_{3}\right)$. Untuk semen PCC yang mengandung senyawa sulfat $\left(\mathrm{SO}_{3}\right)$ dan memang dibuat lebih tahan dengan kondisi tertentu (tahan terhadap reaksi alkali agregat, korosi dan sulfur), perendaman dengan larutan sulfat tidak terlalu berpengaruh pada berat volume beton. Meskipun terjadi penurunan atau peningkatan berat volume, nilainya tidak terlalu besar.

\section{Kuat Tekan}

Pengujian kuat tekan beton dilakukan dengan cara memberikan pembebanan pada benda uji kubus kemudian memcatat beban ultimit (P) pada saat benda uji runtuh,Pengujian kuat tekan dilakukan pada saat benda uji berumur 7 hari, 28 hari, dan 56 hari setelah pengecoran. Dilakukan pengujian pada umur 56 hari karena adanya campwanfly ash (abu terbang) yang menyebabkan penurunan panas hidrasi Penurunan panas hidrasi ini terjadi karena reaksi antara $\mathrm{C}_{3} \mathrm{~S}$ dan $\mathrm{C}_{3} \mathrm{~A}$ terganggu butixanfly ash yang menjadikan rantai reaksi 
akan lebih panjang yang mengakibatkan panas hidrasi akan menurun dan beton akan lebih lama untuk mengeras, Oleh karena itu beton yang dicampur dengan fly ash pengikatan betonnya akan membutuhkan waktu yaug lebih lama daripada beton biasa. Untuk pengujian 7 hari, sampel diangkat 3 hari sebelum pengujian, sedangkan untuk umur pengujian 28 hari dan 56 hari, sampel diangkat dari bak perendaman seminggu sebelum hari pengujian kondisi beton benar benar telah kering. Data yang diperoleh dari hasil pengujian kuat tekan kubus berupa beban maksimum yang diubah menjadi tegangan tekan maksimum dengan menggunakan persamaan berikut :

$$
\sigma_{c}=\frac{P}{A}
$$

dengan:

$$
\begin{aligned}
& \sigma_{\mathrm{c}}=\text { kuat tekan kubus beton }(\mathrm{kg} / \mathrm{cm}) \\
& \mathrm{P}=\text { beban tekan maksimum saat benda uji runtuh }(\mathrm{KM}) \\
& \mathrm{A} \quad=\text { luas penampang kubus beton }(\mathrm{cm})
\end{aligned}
$$

Hasil pengujian kuat tekan beton karakteristik didapatkan dari pengujian kuat rata-rata tiga buah benda uji beton kubus berukuran sisi $15 \mathrm{~cm}$. Beton menggunakan dua jenis semen yang berbeda yaitu semen murni (clinker) dan PCC (Portland Composite Cement). Untuk semen murni ditambahkan fly ash (abu terbang), sedangkan semen PCC digunakan tiga merk yaitu Baturaja, Semen Padang, dan Tiga Roda. Untuk perendaman beton digunakan air biasa dan menggunakan larutan suifat dengan konsentrasi 5\%, karena pada kenyataan sebenarnya, senyawa sulfat ini dapat merusak struktur beton dan menurunkan kekuatan beton. Digunakan konsentrasi 5\% karena konsentrasi sulfat yang ada di alam tidak sampai 5\%, sehingga untuk mengetahui pengaruh terhadap beton yang paling maksimum menggunakan sulfat dengan konsentrasi 5\%. Untuk mendapatkan larutan sulfat dengan konsentrasi 5\% 


\section{Rajiman}

Dewa Gede Putra

harus mencampur dengan air karena larutan sulfat biasanya dijual di pasaran dengan konsentrasi kepekatan 90\% - 100\%. Oleh karena itu larutan sulfat yang dibeli kemudian dicampur dengan air sampai mendapatkan konsentrasi sulfat yang diinginkan. Perhitungan konsentrasi suifat dapat dihitung dengan persamaan berikut :

$$
\mathrm{V}_{1} \cdot \mathrm{M}_{1}=\mathrm{V}_{2} \cdot \mathrm{M}_{2}
$$

dengan:

$$
\begin{array}{lll}
\mathrm{V}_{1} & = & \text { volume awal (liter) } \\
\mathrm{M}_{1} & = & \text { konsentrasi larutan awal (\%) } \\
\mathrm{V}_{2} & = & \text { volume akhir (liter) } \\
\mathrm{M}_{2} & = & \text { konsentrasi larutan akhir (\%) }
\end{array}
$$

Dengan menggunakan persamaan di atas maka bisa didapatkan larutan sulfat

\begin{tabular}{|c|c|c|c|c|c|}
\hline \multirow[b]{2}{*}{ Jenis Semen } & \multirow{2}{*}{$\begin{array}{l}\text { Kandungan } \\
\text { Fly Ash (\%) }\end{array}$} & \multicolumn{3}{|c|}{ Kuat Tekan $\left(\mathrm{kg} / \mathrm{cm}^{2}\right)$} & \multirow{2}{*}{$\begin{array}{c}\text { Peningkatan } \\
\text { Terhadap } 28 \text { Har } \\
\text { pada } 56 \text { Hari }(\%)\end{array}$} \\
\hline & & 7 hari & 28 hari & 56 hari & \\
\hline Semen murni Baturaja & $0 \%$ & 299,26 & 365,19 & 416,30 & 13,99545 \\
\hline Semen murni Baturaja & $5 \%$ & 249,63 & 369,63 & 428,15 & 15,83205 \\
\hline Semen murni Baturaja & $10 \%$ & 288,15 & 389,63 & 462,22 & 18,6305 \\
\hline Semen murni Baturaja & $15 \%$ & 222,22 & 344,44 & 363,70 & 5,591685 \\
\hline Semen murni Baturaja & $20 \%$ & 230,67 & 341,48 & 365,19 & 6,943306 \\
\hline PCC Baturaja & $0 \%$ & 202,22 & $317,78$. & 352,59 & 10,95412 \\
\hline PCC Tiga Roda & $0 \%$ & 222,22 & 293,41 & 380,51 & 29,68542313 \\
\hline PCC Semen Padang & $0 \%$ & 230,67 & 241,89 & 283,12 & 17,04493778 \\
\hline
\end{tabular}
dengan konsentrasi yang diinginkan. Hasil pengujian kuat tekan beton antara semen murni clinker dan PCC disajikan dalam Tabel 5 dan Tabel 6 berikut ini:

Tabel 5. Hasil pengujian kuat tekan beton K300 (Tanpa Perendaman Sulfat) 
Tabel 6. Hasil pengujian kuat tekan beton K300 (Dengan Perendaman Sulfat)

\begin{tabular}{|c|c|c|c|c|c|}
\hline \multirow[b]{2}{*}{ Jenis Semen } & \multirow{2}{*}{$\begin{array}{c}\text { Kandunga } \\
\text { Fly Ash } \\
(\%)\end{array}$} & \multicolumn{3}{|c|}{ Kuat Tekan $\left(\mathrm{kg} / \mathrm{cm}^{2}\right)$} & \multirow{2}{*}{$\begin{array}{c}\text { Peningkatan } \\
\text { Terhadap } 28 \\
\text { hari pada } 56 \\
\text { hari }(\%)\end{array}$} \\
\hline & & 7 hari & $\begin{array}{c}28 \\
\text { hari }\end{array}$ & 56 hari & \\
\hline Semen murni Baturaja & $0 \%$ & 217,04 & 232,59 & 243,70 & 4,776646 \\
\hline Semen murni Baturaja & $5 \%$ & 204,44 & 236,30 & 269,63 & 14,10495 \\
\hline Semen murni Baturaja & $10 \%$ & 210,37 & 248,15 & 276,30 & 11,34395 \\
\hline Semen murni Baturaja & $15 \%$ & 197,04 & 234,81 & 258,52 & 10,09753 \\
\hline Semen murni Baturaja & $20 \%$ & 206,67 & 239,26 & 277,04 & 15,79035 \\
\hline PCC Baturaja & $0 \%$ & 187,41 & 214,81 & 227,41 & 5,865649 \\
\hline PCCTigaRoda & $0 \%$ & 232,15 & 267,41 & 311,85 & 16,61868 \\
\hline PCC Semen Padang & $0 \%$ & 190,37 & 232,89 & 272,59 & 17,04667 \\
\hline
\end{tabular}

\section{Pengaruh Penambahan Fly Ash ke Dalam Semen murni (clinker)}

Dari tabel hasil pengujian kuat tekan di atas dapat terlihat sekali perbedaan kekuatan beton antara beton yang direndam larutan sulfat dengan beton yang direndam dengan air biasa. Pada umur 7 hari beton yang terbuat dari semen murni tanpa penambahan fly ash (kadar fly ash 0\%), kekuatannya mencapai $299,26 \mathrm{~kg} / \mathrm{cm}^{2}$ tanpa perendaman larutan sulfat, sedangkan pada beton yang direndam dengan larutan sulfat dengan konsentrasi 5\%, kuat tekannya hanya $217.04 \mathrm{~kg} / \mathrm{cm}^{2}$.

Pengaruh larutan sulfat lerhadap semen murni ini sangat besar, karena semen murni adalah semen biasa yang tidak memerlukan persyaratan khusus yang terdiri dari terak semen (clinker) dan gypsum tanpa ada bahan tambahan organik lain seperti yang terdapat pada semen PCC, sehingga ketahanan terhadap serangan sulfat berkurang. Pada umur 7 hari penambahan fly ash pada semen murni justru akan mengurangi kekuatan beton karena fly ash mengandung senyawa silika $\left(\mathrm{SiO}_{2}\right)$ dan alumina $\left(\mathrm{Al}_{2} \mathrm{O}_{3}\right)$ yang dapat menyebabkan panas hidrasi dari semen akan menurun dan menyebabkan 


\section{Rajiman}

\section{Dewa Gede Putra}

kekuatan awal menurun. Grafik pengaruh penambahan fly ash terhadap semen murni pada beton umur 7 hari dapat dilihat pada Gambar 2 berikut ini:

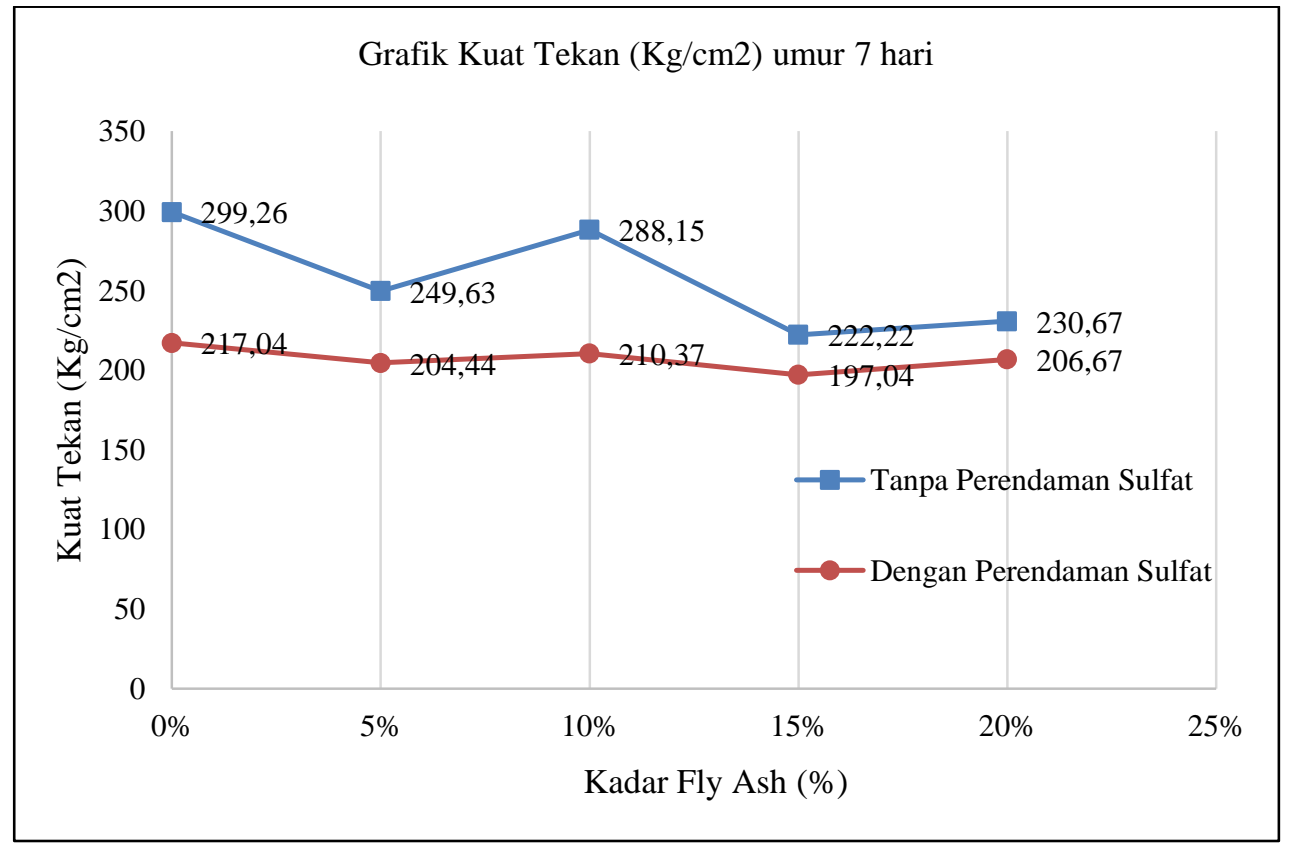

Gambar 2. Kuat Tekan Beton Pada Semen Murni atau OPC Umur 7 Hari

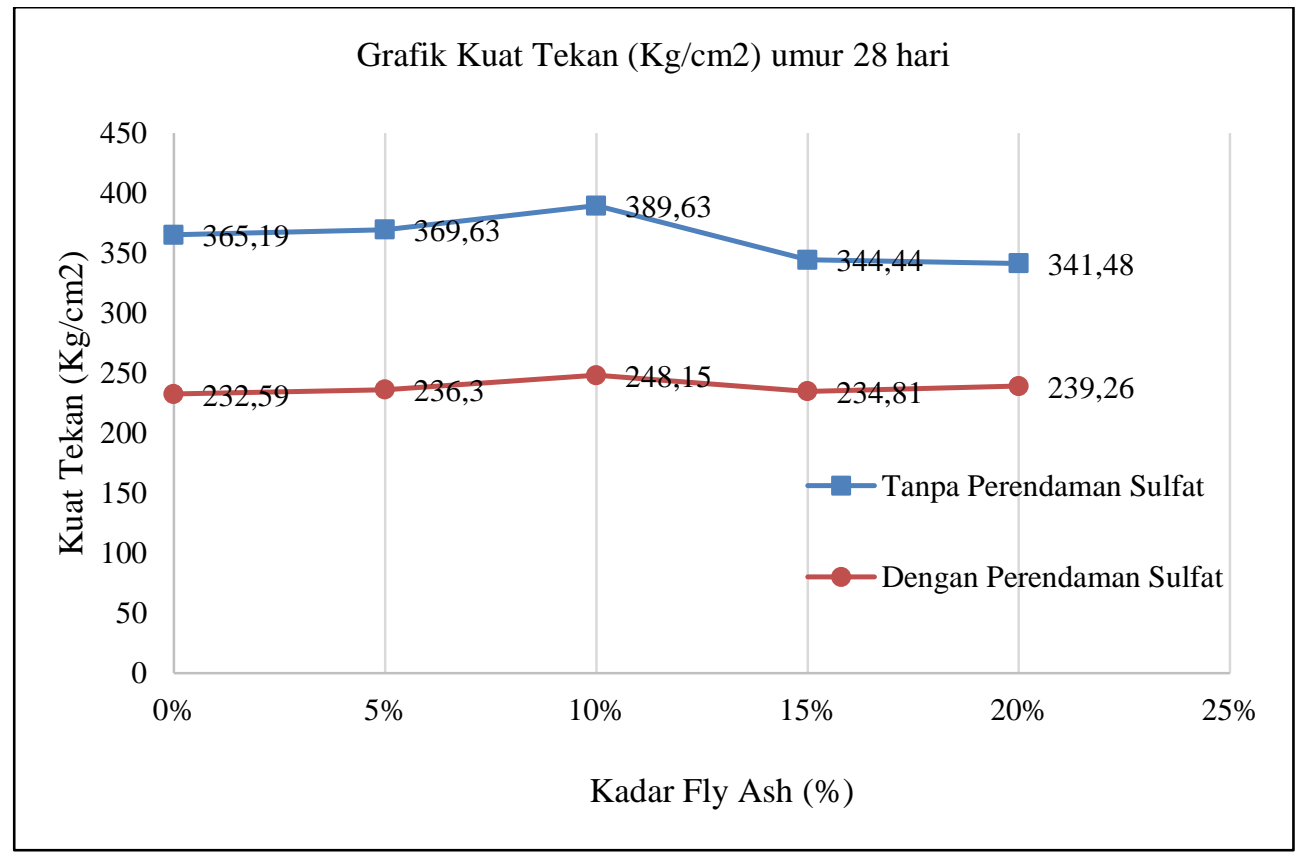

Gambar 3.Kuat Tekan Beton Pada Semen Murni atau OPC Umur 28 Hari 


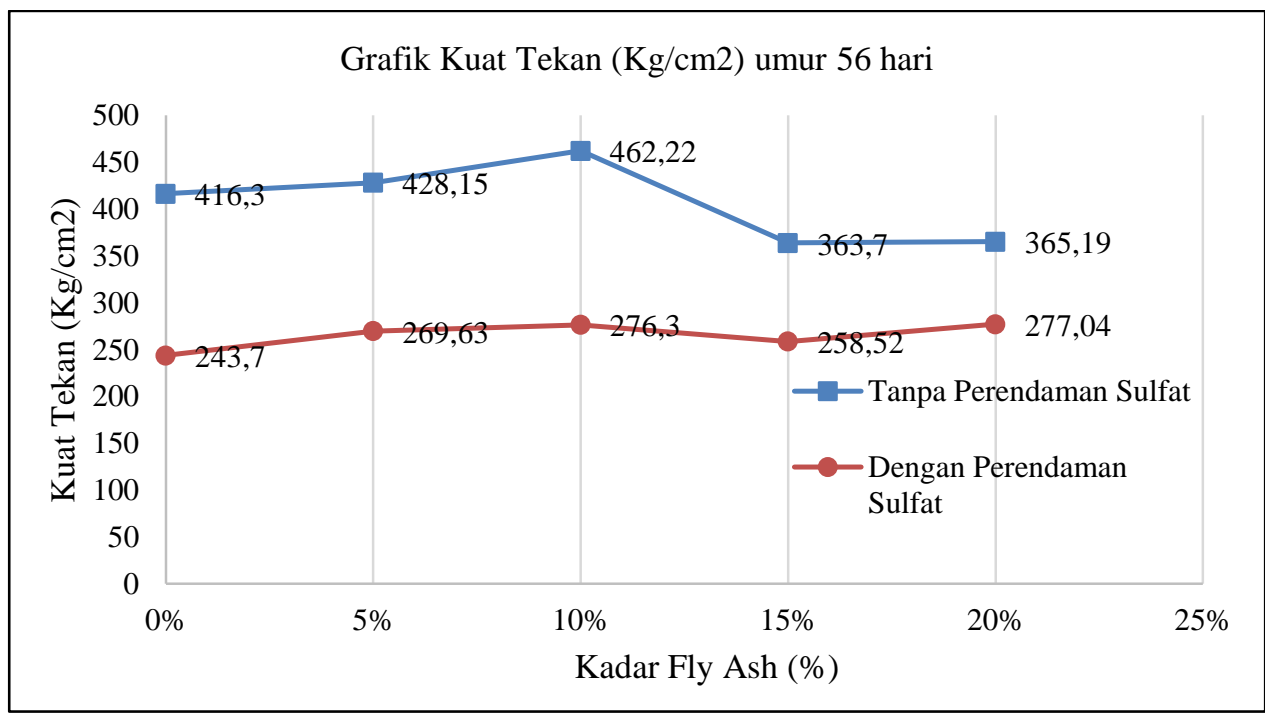

Gambar 4. Kuat Tekan Beton Pada Semen Murni atau OPC Umur 56 Hari

Pada umur 28 hari dan 56 hari dapat terlihat pengaruh penambahan. Fly ash ke dalam semen murni terhadap kekuatannya, baik yang terendam sulfat maupun yang tidak terendam sulfat. Berdasarkan Tabel 5 dan Tabel 6 dapat digambarkan dalam bentuk grafik hubungan kuat tekan beton dengan penambahan fly ash ke dalam semen murni yang disajikan dalam Gambar 3 untuk umur beton 28 hari dan Gambar 4 untuk umur beton 56 hari. Berikut ini adalah tabel persentase perbedaan kuat tekan beton dengan penggunaan fly ash ke dalam semen murni.

Tabel 7. Persentase pengaruh fly ash ke dalam semen murni

\begin{tabular}{c|c|c|c}
\hline Jenis Semen & $\begin{array}{c}\text { Kandungan } \\
\text { Fly Ash }\end{array}$ & $\begin{array}{c}\text { Kuat Tekan } \\
(\mathbf{k g} / \mathbf{c m} 2)\end{array}$ & $\begin{array}{c}\text { Perbandingan } \\
\text { Kuat Tekan (\%) }\end{array}$ \\
\hline \multirow{3}{*}{$\begin{array}{c}\text { Semen murni } \\
\text { Baturaja }\end{array}$} & $0 \%$ & 416.3 & - \\
\cline { 2 - 4 } & $5 \%$ & 428.15 & 2.85 \\
\cline { 2 - 4 } & $10 \%$ & 462.22 & 11.03 \\
\cline { 2 - 4 } & $15 \%$ & 363.7 & -12.64 \\
\hline
\end{tabular}

Tabel 8. Persentase pengaruh fly ash ke dalam semen murni umur 56 hari 
(Pengan Perendaman Sulfat)

\begin{tabular}{c|c|c|c}
\hline Jenis Semen & $\begin{array}{c}\text { Kandungan } \\
\text { Fly Ash }\end{array}$ & $\begin{array}{c}\text { Kuat Tekan } \\
\text { (kg/cm2) }\end{array}$ & $\begin{array}{c}\text { Perbandingan } \\
\text { Kuat Tekan (\%) }\end{array}$ \\
\hline \multirow{4}{*}{$\begin{array}{c}\text { Semen murni } \\
\text { Baturaja }\end{array}$} & $0 \%$ & 243.7 & - \\
\cline { 2 - 4 } & $5 \%$ & 269.63 & 10.64 \\
\cline { 2 - 4 } & $10 \%$ & 276.3 & 13.38 \\
\cline { 2 - 4 } & $15 \%$ & 258.52 & 6.08 \\
\hline
\end{tabular}

Dari Gambar 2 dan Gambar 3 dapat terlihat bahwa kekuatan beton meningkat dengan adanya penambahan fly ash ke dalam campuran beton. Hal ini terjadi karena pada beton umur 28 hari dan 56 hari proses pengikatan beton sudah hampir sempurna. Pengaruh fly ash yang menyebabkan bertambahnya kelecakan dan penurunan panas hidrasi beton sudah tidak berpengaruh. Pada umur 28 hari kekuatan beton maksimum pada penambahan fly ash dengan kadar $10 \%$, baik itu dengan perendaman larutan sulfat ataupun perendaman dengan air biasa. Dalam penelitian Mardiono (2010) juga didapatkan hasil kuat tekan tertinggi pada penggantianfly ash $10 \%$ yaitu mencapai $41,57 \mathrm{Mpa}$ atau sekitar 415,7 kg/cm². Menurut Sebayang (2006), pada umur 7 dan 28 hari kuat tekan beton dengan campuran fly seharusnya lebih rendah dibandingkan dengan beton tanpa campuran fly ash senyawa yang membentuk kekuatan awal pada semen yaitu senyawa $\mathrm{C}_{3} \mathrm{~S}$ dan $\mathrm{C}_{3} \mathrm{~A}$ terganggu dengan adanya fly ash. Karena butiran fan fly ash maka terjadi penurunan panas hidrasi yang menyebabkan rantai reaksi akan lebih panjang dan mengakibatkan beton akan lebih lama untuk mengeras. Dalam penelitian Sebayang (2006) kadar flyash maksimum yaitu pada kadar 20\%. Pada umur 56 hari dengan perendaman air biasa, beton dengan kadar fly ash 10\% masih paling tinggi yaitu sebesar $462,22 \mathrm{~kg} / \mathrm{cm}^{2}$, naik $11,03 \%$ dari beton semen murni yang tanpa fly ash. Namun pada perendaman dalam larutan sulfat, beton dengan kadar fly ash 10\% dan 20\%, kekuatannya hampir sama yaitu sebesar 276,3 dan $277,04 \mathrm{~kg} / \mathrm{cm}^{2}$. Naik $13,38 \%$ dan $13,68 \%$ dari semen 
murni dengan kadar 0\%. Bila dibandingkan terhadap 28 hari, peningkatan kekuatan pada 56 hari paling besar terjadi pada kadar fly ash 10\% dengan kenaikan sebesar $18,63 \%$. Sedangkan pada perendaman sulfat peningkatan paling besar pada kadar fly ash $20 \%$, yaitu sebesar $15,79 \%$ karena pada 28 hari,beton dengan kadar fly ash 10\% kekuatanya sudah tinggi sehingga peningkatan pada 56 hari hanya $11,34 \%$.

\section{Perbandingan Kuat Tekan Antara PCC Baturaja dan OPC Baturaja}

Dari Tabel 4.5 dan Tabel 4.6, apabila semen PCC dari merk Baturaja, pada umur 7 hari, kekuatan beton dari semen murni asal PT. Baturaja ini lebihkuat yaitu $299,26 \mathrm{~kg} / \mathrm{cm}^{2}$ untuk beton yang tidak direndam sulfat dan 217,04 $\mathrm{kg} / \mathrm{cm}^{2}$ untuk beton dengan perendaman sulfat. Sedangkan beton dan semen PCC hanyamemiliki kuat tekan 202,22 kg/ $\mathrm{cm}^{2}$ dan $187,41 \mathrm{~kg} / \mathrm{cm}^{2}$. Menurut Rasyid (2011) kuat tekan beton pada umur 7 hari, beton dari semen murni memiliki panas hidrasi yang lebih tinggi daripada semen PCC sehingga pengikatan awalnya lebih cepat dan menyebabkan kekuatan awalnya juga lebih tinggi. Akan tetapi pada umur 28 hari dan 56 hari, beton dari semen murni Baturaja juga masih lebih kuat dibandingkan dengan beton dari' semen PCC Baturaja. Hasil pengujian kuat tekan beton antara semen murni dan PCC dapat disajikan dalam grafik pada Gambar 5 berikut ini: 


\section{Rajiman}

\section{Dewa Gede Putra}

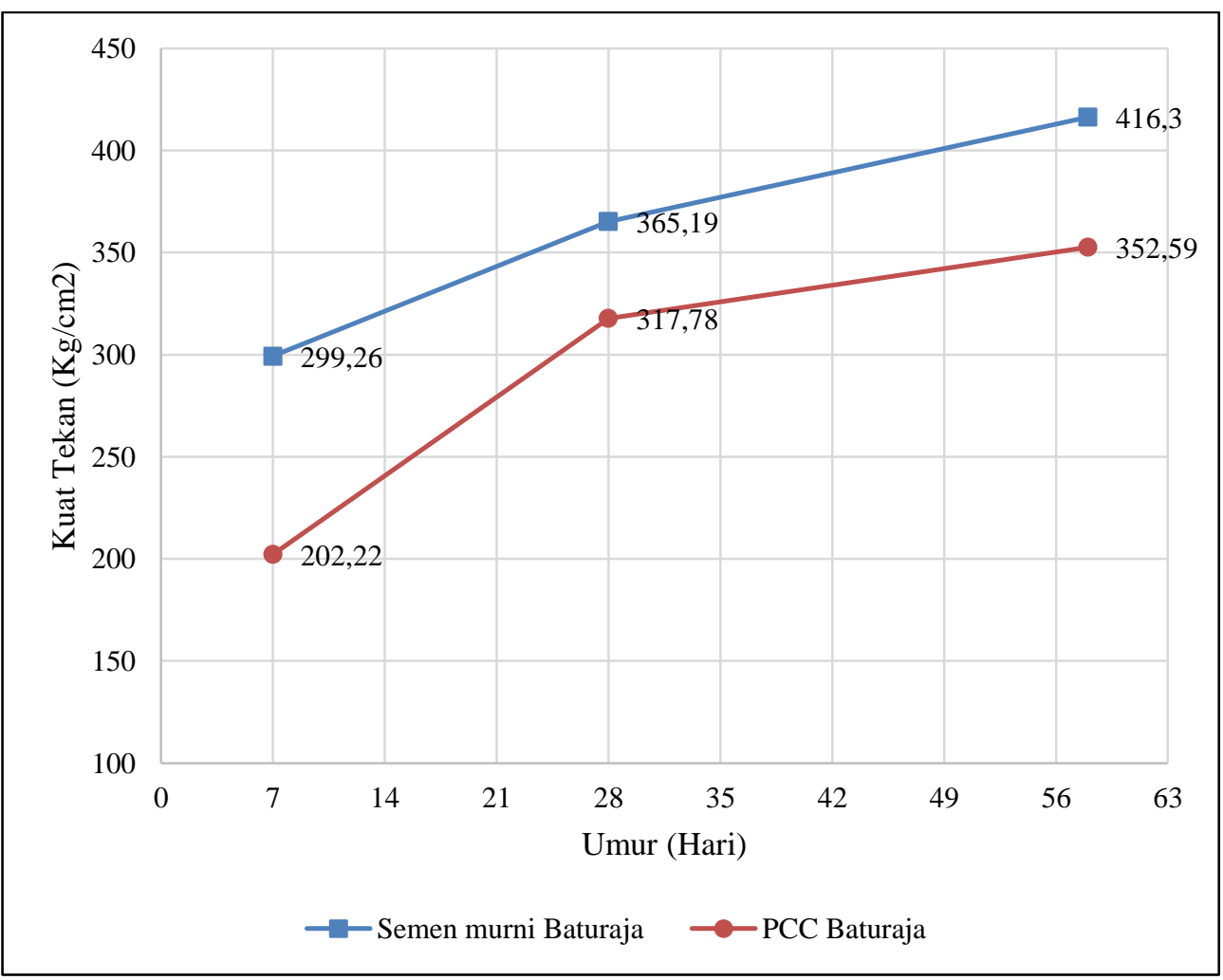

Gambar 5. Perbandingan Kuat Tekan Beton OPC dan PCC Baturaja (Tanpa Perendaman Sulfat)

Gambar di atas adalah perbandingan kuat tekan beton antara semen murni atau OPC dan PCC Baturaja tanpa perendaman dalam larutan sulfat. Terlihat bahwa beton dari semen OPC lebih kuat dibandingkan dengan semen PCC. Dari pengikatan awal 7 hari sampai umur beton 56 hari, beton dari semen murni atau OPC kekuatannya selalu lebih tinggi dibandingkan dengan beton dari semen PCC. Untuk perbandingan kuat tekan beton antara semen OPC dan semen PCC yang direndam larutan sulfat tersaji dalam Gambar 6 berikut ini: 


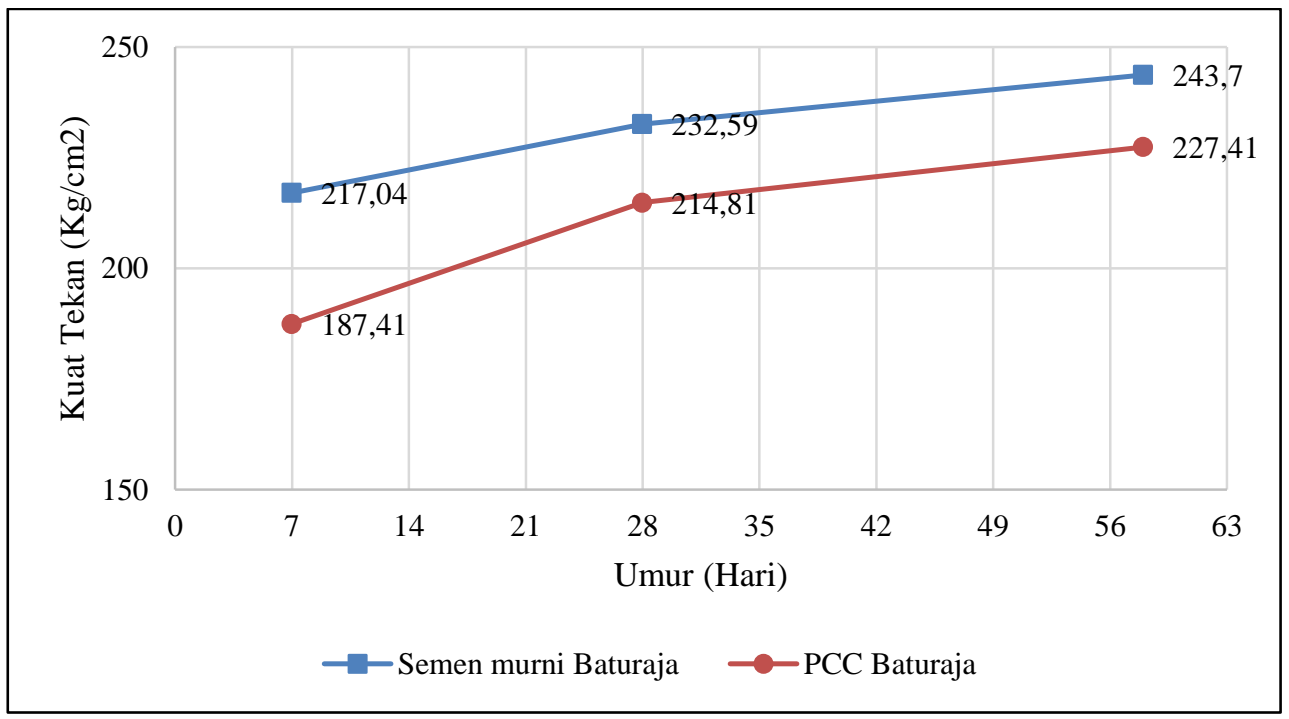

Gambar 6. Perbandingan Kuat Tekan Beton Semen Murni (OPC) dan PCC Baturaja (Dengan Perendaman Sulfat)

Berdasarkan Gambar 6 di atas bisa terlihat bahwa beton dari semen OPC juga lebih kuat dibandingkan semen PCC walaupun direndam dengan larutan sulfat $5 \%$.

\section{Kuat Tekan Antara semen murni (OPC) Baturaja + Fly Ash dengan PCC Baturaja}

Semen PCC didefinisikan sebagai bahan pengikat hidrolis hasil penggilingan bersama-sama terak semen portland dan gips dengan satu atau lebih bahan anorganik, atau hasil pencampuran antara bubuk semen portland dengan bubuk bahan anorganiklain. Dengan kata lain, semen PCC adalah semen murni atau OPC yang ditambah dengan bahan anorganik lain seperti pozzolan, kapur, atau senyawa silikat dengan kadar 6 - 35. Oleh karena itu, dalam penelitian ini akan dibandingkan kekuatan antarabahan tambahan yaitu fly ash dengan semen PCC yang sudah diproduksi olehbaturaja. Berdasarkan 
Tabl 4.5 dan Tabel 4.6, perbedaan kuat tekan antara PCC dansemen murni $(\mathrm{OPC})+$ Fly ash dapat disajikan dalam Gambar 7 berikut ini:

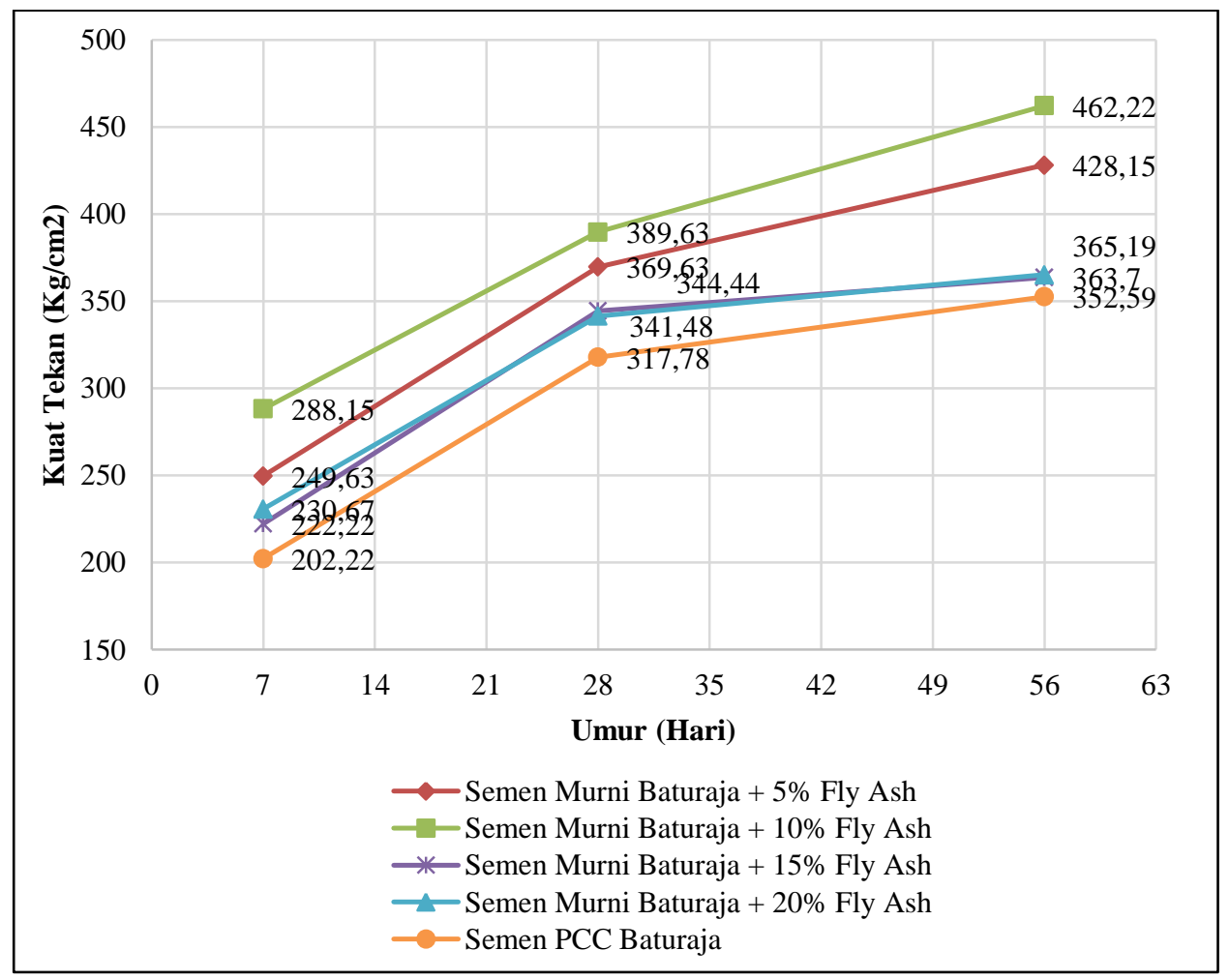

Gambar 7. Perbandingan Kuat Tekan Beton Antara semen murni (OPC) + Fly Ash dan PCC Baturaja (Tanpa Perendaman Sulfat)

Dari gambar di atas dapat terlihat bahwa semen murni atau OPC Baturaja yang ditambah dengan fly ash memiliki kuat token yang lebih tinggi daripada PCC baturaja. Dengan beberapa variasi kadar fly ash, semuanya memiliki kuat lekan yang lebih tinggi dibandingkan dengan PCC Baturaja. Kamun yang paling maksimum adalah semen murni (OPC) $+10 \%$ fly ash yang kekuatannya mencapai $462,22 \mathrm{~kg} / \mathrm{cm}^{2}$ pada umur 56 hari sedangkan PCC Baturaja kuat tekannya hanya $352,59 \mathrm{~kg} / \mathrm{cm}$.

Untuk perbandingan beton yang direndam dalam sulfat dapat dilihat dalam Gambar 7 berikut ini: 


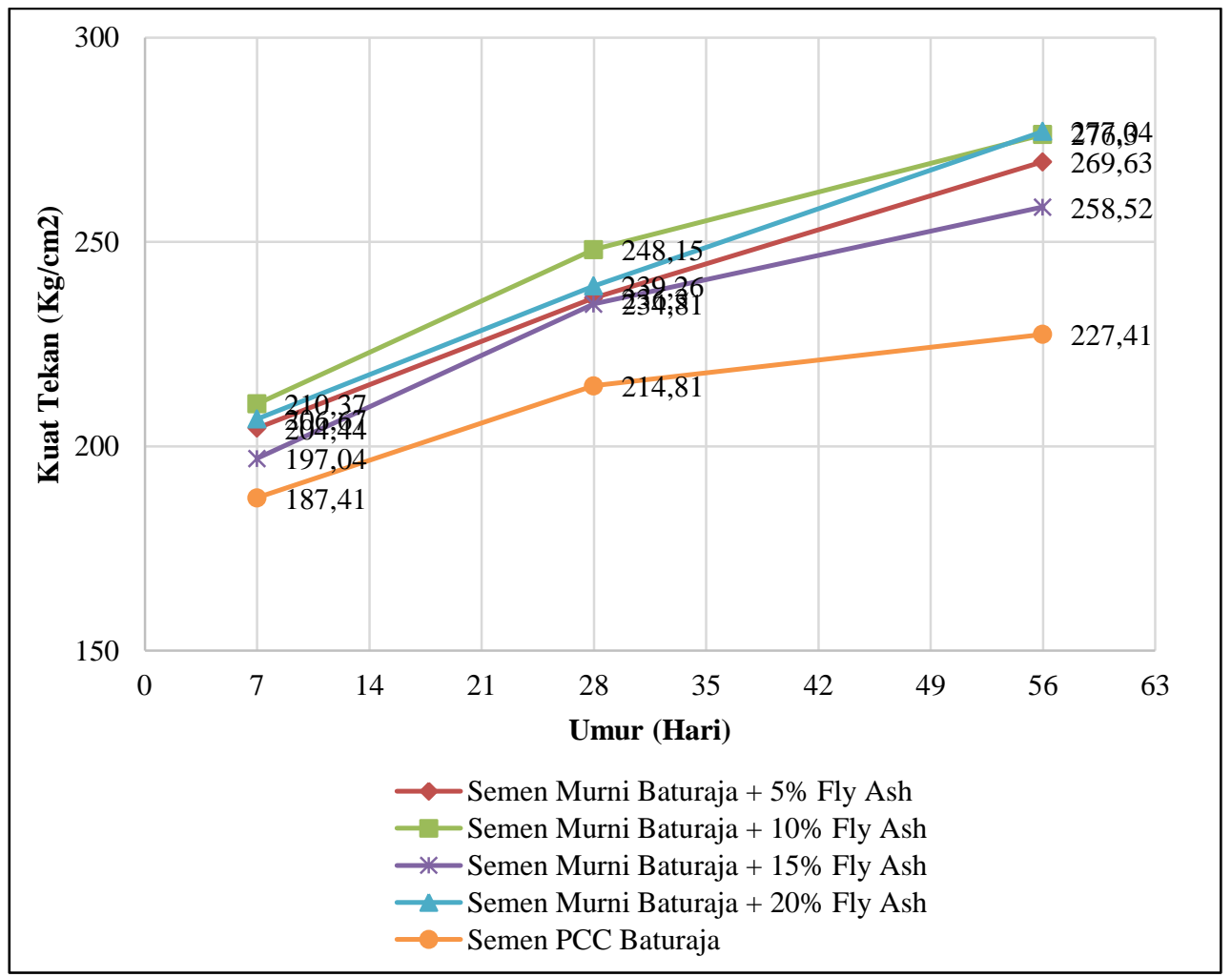

Gambar 8.Perbandingan Kuat Tekan Beton Antara semen murni (OPC) + Fly Ash dan PCC Baturaja (Dengan Perendaman Sulfat)

Berdasarkan grafik di atas dapat dijelaskan bahwa ternyata walaupun dengan larutan sulfat ternyata semen PCC tidak lebih kuat dibandingkan dengan semen murni atau semen murni (OPC) yang ditambah dengan fly ash. Semen murni (OPC) dengan kadar fly ash 10\% masih paling kuat dibanding dengan yang lain yaitu mencapai $276,3 \mathrm{~kg} / \mathrm{cm}^{2}$ sedangkan PCC hanya 227,41 $\mathrm{kg} / \mathrm{cm}^{2}$.

\section{Perbandingan Kuat Tekan Antara semen Murni (OPC) Baturaja Dengan PCC Merk Lain}

Pada penelitian ini juga dilakukan perbandingan hasil pengujian kuat tekan beton dari beberapa jenis semen PCC dari merk lain yaitu merk Tiga Roda 


\section{Rajiman}

\section{Dewa Gede Putra}

dan Semen Padang yang dilakukan dengan perendaman larutan sulfat. Berdasarkan hasil pengujian kuat tekan beton pada Tabel 5 dapat disajikan dalam Gambar 9 berikut ini:

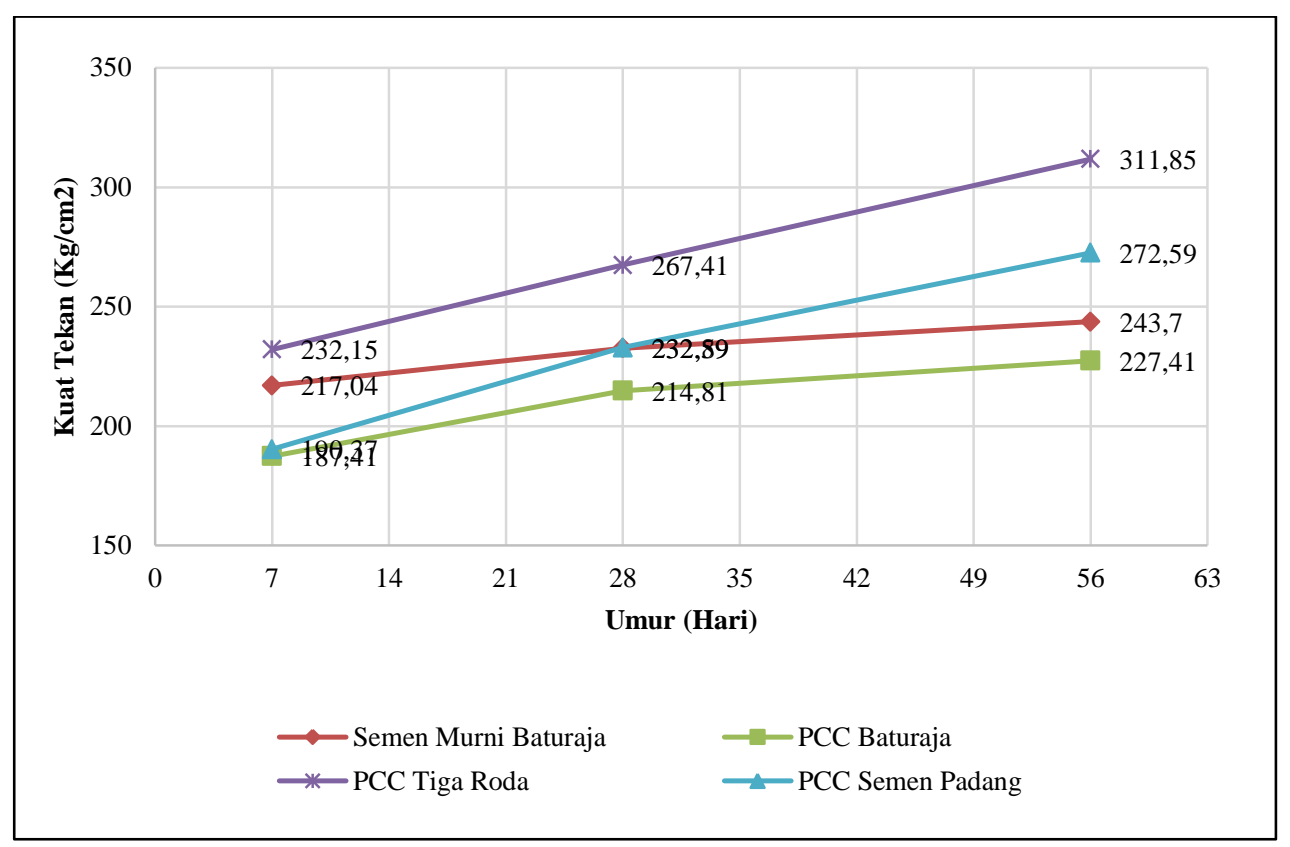

Gambar 9. Perbandingan Kuat Tekan Beton Antara semen murni (OPC)dan

PCC Baturaja dan PCC Merk Lain (Dengan Perendaman Sulfat)

Berdasarkan keterangan Gambar 9 di atas dapat dijelaskan bahwa kuat tekan beton dari semen murni (OPC) Baturaja lebih rendah dari semen PCC dari merk lain pada umur 56 hari. Kuat tekan beton yang paling tinggi ditunjukan oleh semen PCC dari merk Tiga Roda.

Beton dari Semen Padang pada umur beton 7 hari tidak lebih tinggi dari semen murni (OPC) baturaja, namun pada umur beton 56 hari kuat tekan betonnya lebih tinggi dari semen Murni (OPC) Baturaja. Untuk semen PCC Baturaja nilai kuat tekannya paling rendah dibandingkan dengan semen murni (OPC) dari Baturaja sendiri maupun dengan PCC dari merk lain. 
Kuat Tekan AntaraSemen Murni (OPC) Baturaja + Ffy Ash Dengan PCC Merk Lain

Berdasarkan Tabel 7, apabila semen murni (OPC) ditambahkan dengan fly ash maka hasil kuat tekan betonnya bisa bertambah. Dari Tabel 5 dan Tabel 6, kuat tekan beton dari semen murni (OPC) yang paling tinggi saat penambahan fly ash dengan kadar $10 \%$. Grafik perbandingan kuat tekan antara semen $(\mathrm{OPC})+$ fly ash $10 \%$ dengan kuat tekan beton dari semen PCC dapat ditunjukan pada Gambar 10 berikut ini:

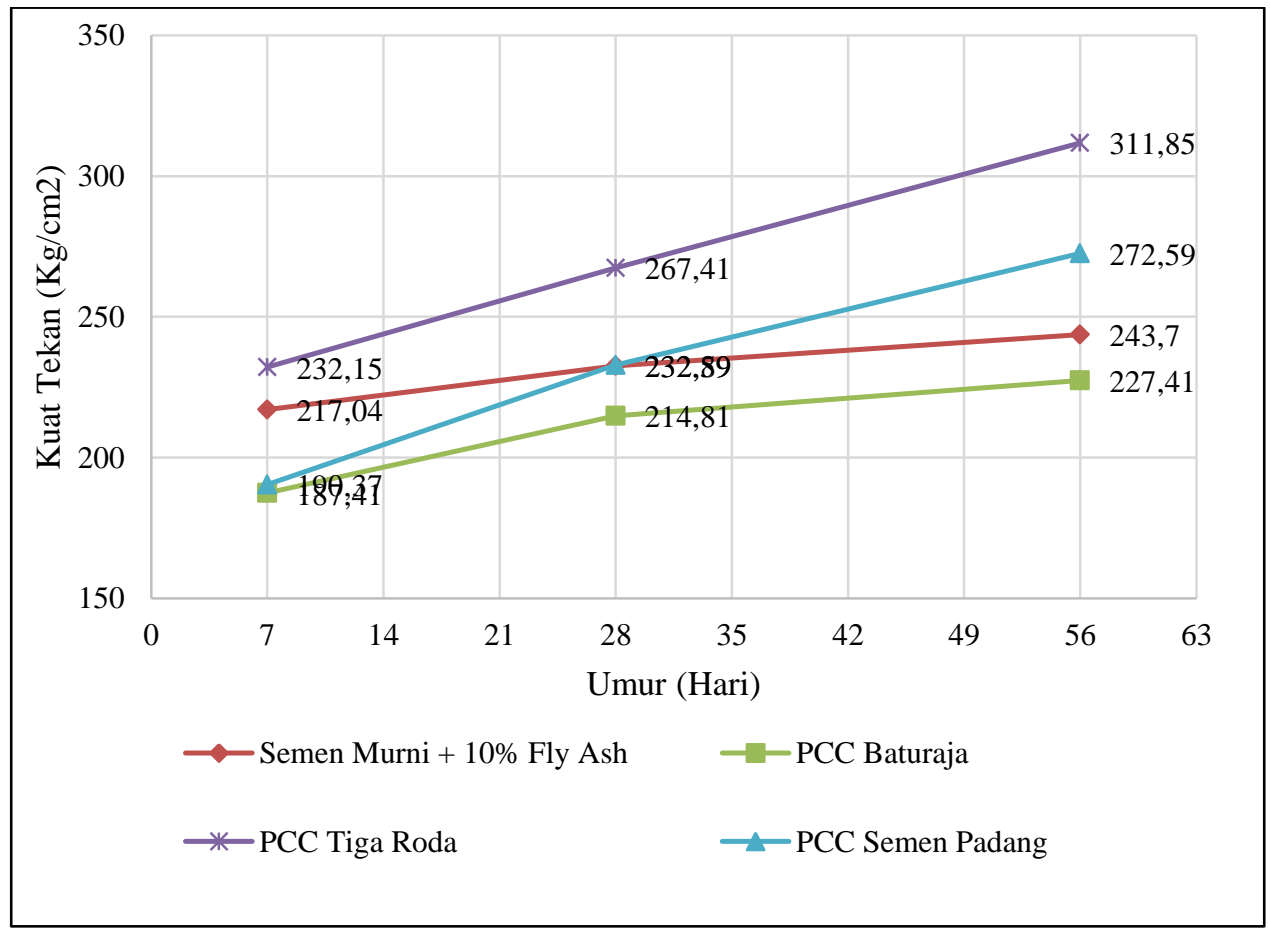

Gambar 10.Perbandingan Kuat Tekan Beton Antara Semen Murni (OPC) + 10\% Baturaja dan PCC Merk Lain (Dengan Perendaman Sulfat)

Berdasrkan grafik di atas menunjukkan adanya peningkatan kekuatan pada beton dari semen murni (OPC) setelah adanya penambahan fly ash dengan kadar $10 \%$, Walaupun terjadi peningkatan kekuatan, namun beton dari semen PCC Tiga Roda masih lebih kuat yang memiliki kuat tekan 311,85 


\section{Rajiman}

\section{Dewa Gede Putra}

$\mathrm{kg} / \mathrm{cm}^{2}$. Akan tetapi bila dibandingkan dengan beton dari PCC Semen Padang, semen murni (OPC) + 10\% fly ash lebih kuat dari umur 7 hari; maupun 56 hari. Berdasarkan keseluruhan pengujian kuat tekan beton, penambahan flyash ke dalam semen murni (OPC) ternyata dapat meningkatkan kuat tekan beton meskipun terjadi penurunan kekuatan pada pengikatan awal. Dalam penelitian Wahyu (2008) hasil pengujian kuat'lekat rata-rata beton normal yang terendam air laut yang mengandung sulfat pada umur 28 hari sebesar 0,5 kgf/mm2, sedangkan beton bahan tambah fly ash dengan variasi persentase $10 \%, 12,5 \%$, dan $15 \%$ sebesar $0,519 \mathrm{~kg} / \mathrm{mm}^{2}$ : $0,593 \mathrm{kgmm}^{2}$ dan $0,459 \mathrm{kgmm}^{2}$, dan hasil kuat lekat rata-rata beton normal pada umur 45 hari sebesar $0,706 \mathrm{kgi} / \mathrm{mm}^{2}$, sedangkan beton bahaa tambah fly ash dengan variasi persentase $10 \%, 12,5 \%$, dan $15 \%$ sebesar $0,720 \mathrm{kgf} / \mathrm{mm}^{2}$; $0,724 \mathrm{~kg} / \mathrm{mm}^{2}$ dan $0,600 \mathrm{kgf} / \mathrm{mm}^{2}$.

Perendaman dalam larutan sulfat dengan konsentrasi 5\% sangat mempengaruhi kuat tekan beton. Hal ini disebabkan karena memang sifat larutan sulfat adalah merusak, baik dari kekuatan beton maupun bentuk fisik dari beton. Oleh karena itu apabila ada bangunan beton dibangun di daerah yang memiliki kadar sulfat seperti di tepi laut, dermaga atau pelabuhan maka lama kelamaan betonnya akan keropos dan mengikis serta berkurang kekuatannya.

\section{KESIMPULAN}

Berdasarkan hasil penelitian dan pembahasan, maka dapat diambil beberapa kesimpulan sebagai berikut:

Penambahan fly ash ke dalam semen murni (klinker) mengindikasikan terjadinya peningkatan kuat tekan pada beton. Dengan kadar fly ash 10\% 
pada umur beton 56 hari menghasilkan kuat tekan paling tinggi yaitu mencapai $462,22 \mathrm{~kg} / \mathrm{cm}^{2}$ atau meningkat $18,6 \%$ tanpa penrendaman sulfat, sedangkan dengan perendaman suflat menghasilkan kuat tekan 276,30 $\mathrm{kg} / \mathrm{cm}^{2}$ atau meningkat $11,34 \%$.

Berdasarkan hasil uji kuat tekan beton, perendaman dalam larutan sulfat mengakibatkan penurunan kuat tekan beton mencapai $59,77 \%$ dan mengalami kerusakan beton secara fisik.

\section{DAFTAR PUSTAKA}

ESDM. (2015). Indonesia Mineral and Coal Information 2015. Jakarta: Direktorat Jendral EDSM Republik Indonesia.

Fadillah, D. A., Sustiawan, F., \& Lee, H. A. (2014). Pengaruh Komposisi Nano Semen Terhadap Kuat Tekan Beton. Jurnal Karya Teknik Sipil Vol 3 No. 4, 1-10.

Fediuk, R., \& Yushin, A. (2015). The use of fly ash the thermal power plants in the construction. IOP Conf. Series: Materials Science and Engineering 93 (2015) 012070, 1-5.

Hasaan, M. (2001). Basalt Rock as an Alternative Raw Material in Portland Cement Manufacture. Materials Letters. Vol. 50. Issue 2-3, 172-178.

Indah Pratama, S. W., Rauf, N., \& Juarlin, E. (2015). Pembuatan dan Pengujian Kualitas Semen Portland Yang Diperkaya Silikat Abu Ampas Tebu. Jurnal Fisika FMIPA Unhas, 1-5.

Lestari, F. (2012). Minimisasi Limbah Pada Industri Semen Dalam Rangka Implementasi Sistem Manajemen Lingkungan Iso 14001. Jurnal AGRIPLUS, Volume 22 Nomor : 02, 110-116.

Miswar, K. (2011). Kuat Tekan Beton Terhadap Lingkungan Agresif. JURNAL PORTAL, ISSN 2085-7454, Volume 3 No. 2, 45-51.

Purba, W. (2014). Analisa Perbandingan Kuat Tekan Beton Menggunakan Portland Composite Cement (PCC) Dan Portland Cemen Type I (PC 1). 
JURNAL TEKNOLOGI Fakultas Teknologi Industri, Volume 4, No. 2, 47-55.

SNI. (2002). Tata cara perhitungan struktur beton untuk bangunan gedung. Jakarta: Badan Standarisasi Nasional.

Suarnita, I. W. (2011). Kuat Tekan Beton dengan Aditif Fly Ash Ex. PLTU Mpanau Tavaeli. Jurnal SMARTek, Vol. 9 No. 1, 1-10.

Syafpoetri, N. A., Monita, O., \& Lita, D. (2013). Pemanfaatan Abu Kulit Kerang (Anadara Grandis) Untuk Pembuatan Ekosemen. Jurnal Teknik Sipil Universitas Riau, 1-14.

Tekmira. (2016, Mart 14). Informasi Mineral dan Batu Bara. Retrieved from www.tekmira.esdm.go.id:

http://www.tekmira.esdm.go.id/data/Timah/ulasan.asp?xdir=Timah\& commI d=31\&comm=Timah 